\begin{tabular}{l} 
Missio Ecclesiae \\
ISSN 2086-5368 (Print) \\
ISSN 2086-5368 (Online) \\
https://jurnal.i3batu.ac.id/index.php/me \\
Vol.10, No.1, pp. 1-18, 2021 \\
\hline
\end{tabular}

\title{
Model Kemartiran Dalam Penginjilan Rasul Paulus Berdasarkan Kisah Para Rasul Terhadap Kelompok Kabar Baik Di Malang
}

\author{
Tri Hananto ${ }^{a}$,Erni M.C. Efruan ${ }^{b}$ \\ ${ }^{a}$ Sekolah Tinggi Alkitab Nusantara Malang,tryhanto@yahoo.com \\ ${ }^{b}$ Institut Injil Indonesia, erniefruan63@gmail.com
}

\section{INFO ARTIKEL \\ Sejarah Artikel: \\ Diterima: Oktober 2020 \\ Direvisi: Oktober 2020 \\ Disetujui: April 2021 \\ Dipublikasi: April 2021}

Kata Kunci:

Kemartiran,

penginjilan,

Keywords:

The Martyrdom,

Evangelism.

\begin{abstract}
ABSTRAK
Pada mulanya tindakan menjadi seorang martir masih sebatas sebagai saksi hidup atas suatu peristiwa yang dilihat dengan mata sendiri. Martir identik dengan orang-orang yang melihat peristiwa secara langsung dan memberikan kesaksian atas peristiwa yang dialami atau dilihatnya. Namun setelah peristiwa penyampaian Amanat Agung dimana Tuhan memberikan perintah untuk menjadikan segala bangsa sebagai muridNya, martir yang dulunya masih sebatas saksi telah berkembang menjadi sebuah tindakan dimana demi sebuah kesaksian kebenaran yang dilihat rela menderita bahkan mati demi kesaksian yang dipercayainya. Tindakan ini disebut sebagai tindakan kemartiran.

Salah seorang saksi mata atas kebenaran Injil dan juga menjadi pemberita atas kebenaran itu adalah Paulus, yang sebelumnya menjadi penganiaya terhadap para pengikut Yesus. Dalam pemberitaan Injilnya Paulus rela menghadapi banyak kesulitan, tantangan, penderitaan, penganiayaan bahkan sampai kematian. Tindakan menjadi martir Kristus atau kemartiran telah menjadikan Paulus bukan hanya berbicara sebagai saksi mata atas kebenaran yang dipercayai namun juga mati demi kebenaran yang dipercayai.

Dengan pemahaman itu peneliti mengadakan Penelitian yang ditulis berdasarkan obyek kemartiran dalam penginjilan rasul Paulus berdasarkan kitab Kisah Para Rasul terhadap Kelompok Kabar Baik di Malang. Dengan menggunakan pendekatan kualitatif dan menggunakan metode fenomenologi dengan paradigm naturalistik. Tujuan dari penelitian ini untuk menjelaskan dan menemukan: (1) Kemartiran dalam penginjilan rasul Paulus berdasarkan kitab kisah Para Rasul; (2) Kemartiran dalam penginjilan Kelompok Kabar Baik di Malang; (3) Model kemartiran dalam penginjilan rasul Paulus berdasarkan kisah Para Rasul terhadap Kelompok Kabar Baik di Malang. Pengumpulan data dalam penelitian ini dilakukan melalui observasi, wawancara dan pengkajian dokumen tertulis. Sedangkan analisis datanya menggunakan analisa domain, analisa taksonomi, analisa komponensial dan analisa tema. Dan hasil dari penelitian ini ditemukan suatu model yaitu model strategi bersaksi sampai garis akhir yang ditopang berdasarkan prinsip-prinsip kemartiran rasul Paulus berdasarkan kisah para rasul dan dengan memperhatikan tantangan yang ada dalam pelayanan serta ditopang oleh keteladanan hidup yang berdasarkan kebenaran firman Tuhan.
\end{abstract}


Initially, the act of becoming a martyr was limited to being a living witness of an event that was seen with one's own eyes. Martyrs are synonymous with people who see events firsthand and give testimony of events they have experienced or seen. However, after the delivery of the Great Commission where God gave orders to make all nations His disciples, the martyr, who was only a witness, has developed into an act where for the sake of a testimony of the truth that is seen, he is willing to suffer and even die for the testimony he believes. This act is known as an act of martyrdom.

One eyewitness to the truth of the gospel and also a preacher of that truth was Paul, who had previously been a persecutor of the followers of Jesus. In preaching the gospel, Paul was willing to face many difficulties, challenges, suffering, persecution, and even death. The act of being martyred by Christ or martyrdom had Paul not only spoke as an eye witness to the truth that was believed but also died for the truth that was believed.

With that understanding, the researcher conducted a study written based on the object of martyrdom in the evangelism of the apostle Paul based on the book of Acts of the Kelompok Kabar Baik in Malang. By using a qualitative approach and using the phenomenological method with a naturalistic paradigm. The purpose of this research is to explain and discover: (1) martyrdom in the evangelism of the apostle Paul based on the book of the Acts of the Apostles; (2) Martyrdom in evangelizing the Kelompok Kabar Baik in Malang; (3) The model of martyrdom in the apostle Paul's evangelism is based on the story of the Apostles against the Kelompok Kabar Baik in Malang. Data collection in this study was carried out through observation, interviews, and review of written documents. While the data analysis uses domain analysis, taxonomic analysis, compositional analysis, and theme analysis. And the results of this study found a model, namely a model of witnessing strategy to the finish line which is supported based on the principles of the martyrdom of the apostle Paul based on the story of the apostles and by paying attention to the challenges that exist in ministry and is supported by an example of a life based on the truth of God's word.

\section{PENDAHULUAN}

Dalam rencana-Nya untuk menebus dan menyelamatkan manusia yang berdosa, Allah mengaruniakan Anak-Nya yang tunggal, Yesus Kristus berinkarnasi ke dalam daging menjadi seorang manusia sejati yang menyerahkan nyawa-Nya di atas kayu salib untuk menebus manusia dari segala dosa dan pelanggaran, setelah itu bangkit pada hari yang ketiga memberikan anugerah keselamatan kekal bagi setiap orang yang percaya kepada-Nya. Dan Setelah kebangkitan, Yesus mengumpulkan para murid di suatu tempat menjelang kenaikanNya ke Sorga. Yesus memberikan sebuah amanat terakhir, sebuah perintah untuk dilakukan oleh para pengikut-Nya, yang dikenal secara populer sebagai Amanat Agung, yang tertulis dalam kitab Mat 28:18-20. Amanat Agung merupakan bagian penting dalam kehidupan kekristenan ataupun kehidupan gereja (Sills 2015)

Inti dari Amanat Agung sejatinya adalah sebuah kegiatan pemuridan (Yun: $\mu \alpha \theta \eta \tau \varepsilon u ́ \sigma \alpha \tau \varepsilon$ - Mat 28:19-20). Dengan menjadikan semua orang sebagai murid Kristus bukan sekedar menjadi pengikut. Dan langkah-langkah yang dikerjakan untuk menjadikan murid adalah dengan cara: Pergilah, yang ditulis $\pi$ o $\rho \varepsilon v \theta \varepsilon ́ v \tau \varepsilon \varsigma$ - Poreuthentes : Yun(Alkitab elektronik: Bibleworks ver. 8 n.d.) yang menunjuk pada suatu tindakan untuk meninggalkan suatu tempat menuju ke tempat lain yang melintasi batas-batas budaya, geografis dan bahasa untuk memberitakan Injil keselamatan(Nielsen 2015); Baptislah, dituliskan Yun: $\beta \alpha \pi \tau i \zeta o v \tau \varepsilon \varsigma$ (baptizontes) yang berasal dari akar kata $\beta \alpha \pi \tau i \zeta \omega$ (baptizo), yang artinya direndam atau dicelupkan, yaitu tindakan setelah seseorang menerima keselamatan sebagai bentuk ikrar kepercayaan kepada Bapa, Anak dan Roh Kudus Allah yang esa(Sutanto 2006); Ajarlah, yang dituliskan Yun: $\delta \mathrm{i} \alpha \sigma \sigma \kappa v \tau \varepsilon \varsigma$ (didaskontes), merupakan tindakan yang 
membawa transformasi dari Amanat Agung Tuhan Yesus, dimana para murid diminta untuk mengajarkan segala Firman Tuhan yang sudah didengarkan dan dialami kepada semua bangsa agar bertumbuh menuju kesempurnaan Kristus (Nielsen 2015) dan setelah Tuhan memberikan perintah untuk menjadikan segala bangsa sebagai muridNya maka selanjutnya ditopang dengan penyertaan kekal.

Namun konsekuensi yang harus dibayar atas kegiatan pemberitaan Injil dan atas kepercayaan kepada Kristus adalah penderitaan bahkan kematian demi keselamatan jiwajiwa yang terhilang (Kol 1:24; 1Tes 2:14). Sehingga ini telah menjadi prinsip-prinsip yang sangat penting dalam pemberitaan Injil atau penginjilan. Seperti yang pernah disampaikan oleh Tuhan Yesus," ... kalian akan ditangkap dan dianiaya. Kalian akan diadili di rumahrumah ibadat dan dimasukkan ke dalam penjara. Dan kalian akan diseret ke hadapan rajaraja dan penguasa-penguasa karena kalian pengikut-Ku. Itulah kesempatan bagimu untuk memberitakan Kabar Baik dari Allah.” (Luk 21:12-13). Serta peneguhan bagi seorang murid, "Setiap orang yang mau mengikut Aku, ia harus menyangkal dirinya, memikul salibnya setiap hari dan mengikut Aku." (Luk 9:23). Jadi Setiap orang yang mau menjadi murid Kristus harus siap dengan segala tantangan dan penderitaan, siap melakukan penyangkalan diri, siap dalam memikul salib setiap hari, mengalami malu dan penghinaan. S.J Samartha mengatakan,"Salib adalah lambang penerimaan akan penderitaan untuk menggenapi maksud kasih dalam realita sejarah manusia."(Yewangoe 1989). Salib dan kematian Kristus memperlihatkan bagaimana kuasa kejahatan dan tragedi dalam kehidupan manusia ditaklukkan oleh kasih. Penderitaan yang dialami bahkan sampai pada kematian dari para saksi Kristus yang sering disebut sebagai martir Kristus menunjukkan kepada orang kristen bagaimana rasanya berdiri teguh dalam iman kepada Yesus dan tidak menyangkalNya (Estabrooks 2001).

Dalam Injil Yohanes 15:20 dikatakan,"...Jikalau mereka telah menganiaya Aku, mereka juga akan menganiaya kamu..." di perikop yang sama Yesus juga memberitahukan kepada para murid-Nya, bahwa dunia akan membenci mereka karena mereka memilih untuk hidup keluar dari dunia (ayat 18-19). Para pengikut Kristus akan dibenci, dianiaya, dan ditolak selama hidup didunia ini. Dunia merupakan musuh yang keras yang akan selalu menentang Allah dan prinsip-prinsip kerajaan-Nya, baik itu meliputi organisasi-organisasi keagamaan, gereja-gereja palsu serta orang-orang yang tidak percaya Kristus. Dalam 2 Tim 3:12 juga dikatakan "Memang setiap orang yang mau hidup beribadah di dalam Kristus Yesus akan menderita aniaya". Jadi orang-orang Kristen yang telah dipanggil keluar dari dunia akan mengalami penderitaan meski memiliki kehidupan yang saleh sekalipun(Estabrooks 2001).

Kelompok Kabar Baik adalah kelompok penginjil yang memiliki pola pendekatan dalam pemberitaan Injil terkesan menghindar dari konflik, perdebatan atau benturan secara langsung dengan orang-orang yang diinjili. Jika seseorang menolak mendengar berita Injil yang diberitakan, kelompok ini akan beralih ke orang lain yang bersedia menerima pemberitaan. Sebab prinsip mereka dalam memberitakan injil adalah sekedar memberitakan sedang wewenang membawa orang bertobat adalah pekerjaan Roh Kudus sendiri (Yoh 16:8; 15:26). Sekalipun kelompok ini berpandangan bahwa tidak takut menghadapi tantangan atau penderitaan demi pemberitaan injil. Namun dengan dasar penginjilan yang diterapkan seperti itu akan terhindar dari kesan martir. Mungkin juga karena dalam memberitakan injil di Indonesia harus sangat hati-hati, untuk tidak menyinggung keyakinan kepercayaan lain sehingga tidak akan terkena pasal penistaan agama (UU peninstaan Agama). Dengan melihat prinsip penginjilan kelompok ini maka penulis meneliti tentang prinsip kemartiran yang diterapkan berdasarkan prinsip kemartiran yang dialami oleh rasul Paulus. Dengan harapan dapat menemukan prinsip kemartiran yang sesuai dengan pola penginjilan kelompok. 


\section{KAJIAN LITERATUR}

Kajian literatur ini membahas segala sesuatu yang berkaitan dengan kemartiran, baik itu tentang pengertian, sejarah kemartiran, konsep kemartiran maupun spiritualitas dalam kemartiran.

\section{Pengertian Martir}

Martir merupakan bentuk kata benda yang dalam bahasa Inggris dituliskan "martyr

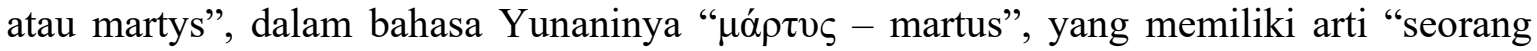
saksi" atau "orang yang memberi kesaksian". Kata ini sebenarnya memiliki beberapa arti, diantaranya : (1). Menunjuk pada satu pribadi yang memilih untuk menderita atau mati daripada menyerahkan imannya atau prinsip-prinsipnya; (seseorang yang dianiaya atau dibunuh karena menjadi saksi atas kepercayaannya); (2). Menunjuk pada seorang yang menderita kesakitan besar dalam waktu yang lama mengalami penganiayaan (Takaliuang n.d.)

Kata martir umumnya dipakai untuk orang-orang yang berkorban, sering kali sampai mati, namun dalam praktik hidup gereja masa kini, kata "martir" identik dengan sebuah kesaksian hidup dalam mempertahankan iman sampai mati. Jadi, ungkapan "martir" menjadi identik dengan pengorbanan nyawa.

Sedangkan Martir dalam bahasa Arab disebut "Syahid", dimana memiliki pengertian tentang seseorang yang meninggal dalam perjuangan demi keyakinan atau imannya, sebagai contoh pada peristiwa yang terjadi pada masa penganiayaan terhadap orang-orang Kristen perdana di kekaisaran Romawi. Tetapi istilah ini juga sering diberikan terhadap mereka yang menggunakan kekerasan, seperti pada orang yang meninggal demi membela Negara pada masa perang (Takaliuang n.d.)

Menurut Encyclopedia Britannica, martir memiliki arti:

Orang yang secara sukarela menderita kematian daripada menyangkal keyakinannya dengan kata-kata atau perbuatan. Istilah ini juga dapat merujuk pada siapa saja yang mengorbankan hidupnya atau sesuatu yang sangat berharga demi prinsip keyakinannya(Ensiklopedia Alkitab Masa Kini, jilid II M-Z n.d.)

Kata martir yang bermakna "saksi" atau "orang yang memberi kesaksian", akan memberikan sebuah dampak yang langsung dapat dirasakan, baik kualitas imannya maupun ketaatannya kepada Allah. Penderitaan yang dialami secara fisik dalam jemaat gereja mulamula sangat dihormati dan dihargai, seperti kematian para rasul, diakon (Stefanus) dan para bapa gereja (Polycarpus, Ignatius, dll). Bahkan ada semboyan dalam gereja mula-mula (Orthodoks) bahwa "Darah para martir merupakan air kehidupan bagi gereja"(Tertullian 1885) Dan hari-hari kematian mereka sebagai martir diperingati oleh gereja sebagai pahlawan iman dan dimasukkan dalam kitab Synaxarium sebagai pembelajaran spiritual. Contoh yang terekam dalam kitab suci seperti kisah Stefanus, Paulus dan orang-orang kudus.

Seorang martir juga memberikan teladan hidup yang sangat total dalam mempraktikan kitab suci seperti teladan hidup Tuhan Yesus, para nabi, para rasul, dan bapabapa gereja, para rahib. Ketaatan tersebut diatas rata-rata kedisiplinan awam dalam memandang kehidupan kudus seperti berdoa dan berpuasa, bersedekah, pembacaan kitabkitab suci. Hidup dalam kedisiplinan rohani tersebut semata-mata menjadi sebuah bentuk pengabdian bagi Tuhan Yesus sebagai Sang Raja. Kehidupan yang taat dan disiplin rohani tersebut juga dipandang sebagai martir, seperti pendapat rasul Paulus. "Tetapi aku melatih tubuhku dan menguasainya seluruhnya, supaya sesudah memberitakan Injil kepada orang lain, jangan aku sendiri ditolak" (1 Kor 9:27 (TB). "Karena itu, saudara-saudara, demi kemurahan Allah aku menasihatkan kamu, supaya kamu mempersembahkan tubuhmu 
sebagai persembahan yang hidup, yang kudus dan yang berkenan kepada Allah: itu adalah ibadahmu yang sejati”. (Rm 12:1 (TB).

Jadi berdasarkan beberapa pemaparan mengenai pengertian tentang martir maka dapat disimpulkan bahwa martir merupakan seseorang yang memilih untuk menderita atau mati dalam memberikan kesaksian mengenai kebenaran yang diyakininya daripada menyerahkan imannya atau prinsip-prinsip kepercayaannya. Martir adalah seseorang yang memberikan keteladan dalam hidupnya secara total dalam mempraktekan kebenaran firman Allah. Martir bukan hanya mengenai kematian atau sesuatu yang mengerikan tetapi martir seperti jalan baru, bentuk kelahiran baru untuk memasuki kehidupan kekal (Malaty 1995). Esensi menjadi martir adalah menjadi saksi bagi Kristus, dan dalam kekristenan martir merupakan seorang yang berkomitmen untuk menjadi saksi dalam pemberitaan kebenaran iman dalam Kristus Yesus, yang bersedia mengalami kesulitan, penderitaan bahkan sampai kepada kematian, demi membawa orang kepada pertobatan dan keselamatan. Semangat kemartiran dalam pemberitaan Injil harus terus digelorakan dari generasi ke generasi.

Sedangkan kata kemartiran (martyrdom) yang berasal dari akar kata martir, menunjuk pada suatu tindakan yang dilakukan oleh seorang saksi atau seorang martir(syahid-dlm Islam) dalam memberitakan kebenaran yang diyakininya (yaitu iman kepada Kristus) dan mempertahankan imannya untuk dipersatukan dengan Allah (Malaty 1995) dimana kata ini pertama kali dipergunakan untuk para rasul yang menyaksikan iman mereka.

Kemartiran juga merupakan serangkaian peristiwa penyiksaan, penderitaan penjara, penganiayaan atau persekusi hingga berujung pada penderitaan yang sangat berat bahkan pada kematian demi mempertahankan iman dan tidak menyangkalnya. Penyiksaan yang dialami biasanya berkaitan dengan pemaksaan penyangkalan iman. Kemartiran merupakan resiko dan tanggung jawab bagi setiap orang kristen, karena ini seperti yang pernah tertulis dalam Mat 5:10-12, bahwa berbahagialah orang yang dianiaya karena nama Yesus. Ada juga pernyataan yang tertulis bagi para pengikut Yesus bahwa," ... kamu akan diserahkan supaya disiksa, dan kamu akan dibunuh dan akan dibenci semua bangsa oleh karena nama-Ku," (Mat 24:9). Kemartiran dalam iman Kristen adalah sebuah kehormatan karena kematian orang-orang yang dianiaya karena nama Yesus adalah yang empunya kerajaan Allah. Dalam Yoh 16:2 disebutkan," kamu akan dikucilkan, bahkan akan datang saatnya bahwa setiap orang yang membunuh kamu akan menyangka bahwa ia berbuat bakti bagi Allah."

\section{Sejarah Kemartiran}

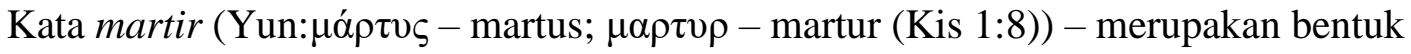
kata benda nominatif maskulin jamak, yang memiliki arti secara harafiah "saksi" atau "orang yang memberikan kesaksian". Kata ini mengacu pada saksi atas iman. Pada mulanya Istilah ini sering dipergunakan untuk mereka yang telah melihat peristiwa atau kejadian sehingga menjadi saksi atas kejadian tersebut (Takaliuang n.d.) Dalam kekristenan awal para Rasul adalah "saksi" dari kehidupan Yesus dan "saksi" atas pengajaran yang disampaikan-Nya. Sebagai saksi Kristus para Rasul diperhadapkan pada bahaya yang besar, menderita yang besar atas kepercayaan mereka. Para rasul sering diperhadapkan pada penyangkalan atas yang dilihat atau diyakini atau menghadapi eksekusi. Jadi dari sini martir merujuk pada seseorang yang rela dengan senang hati untuk menderita bahkan mati daripada menyangkal imannya.

Dalam Kis 1:8 ini, sebelum frasa kata martir didahului dengan kata "kuasa", dimana kata ini memiliki makna "keberanian" pada saat Roh Kudus turun atas mereka. Dan pada kata ini juga diperjelas dengan penggunaan kata "tetapi" ( $\dot{\alpha} \lambda \lambda \grave{\alpha}$, alla). Yang memiiki penekanan pada mengarahkan para murid kepada kuasa Roh Kudus yang akan turun atas mereka, memampukan untuk menjadi saksi-saksi Kristus(Witherington III 1998). Jadi 
sebelum menjalankan mandat Kristus sebagai saksi-Nya, para murid diberikan topangan kuasa Roh Kudus yang dicurahkan. Kuasa Roh Kudus inilah yang nantinya akan menjadi spirit dalam pelayanan para murid.

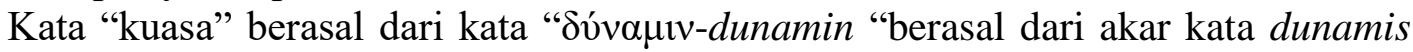
yang diterjemahkan sebagai power (kuasa) serta strength(kekuatan) (Mat 14:2; 22:29; Kis 1:8; Rm 1:4; Kol 1:11; 2 Tim 3:5; Ibr 7:16; 2 Pet 1:3). Dan secara sederhana kata dunamin diterjemahkan sebagai suatu kuasa, kekuatan dan kemampuan dapat mengerjakan segala sesuatu sampai selesai. Jadi dengan dunamis dari Roh Kudus para murid akan dimampukan, diperlengkapi untuk memberikan kesaksian (Peterson 2009). Bahkan dunamis ini akan menjadi kekuatan bagi para murid Kristus untuk mendobrak segala halangan dan rintangan dalam memberitakan injil.

Kata dunamis digunakan oleh Lukas dalam Kisah Para Rasul sebanyak sepuluh kali dalam pemakaian dengan beberapa konteks (Barret 2004). Sebanyak tiga kali dalam (Kis $2: 22 ; 8: 13 ; 19: 11$ ) yang menunjuk kepada kuasa dalam mujizat-mujizat; sebanyak tiga kali dipergunakan untuk menjelaskan tentang kuasa yang menyebabkan terjadinya mujizat (Kis $3: 12 ; 4: 7 ; 10: 38)$. Juga dipergunakan sebanyak dua kali yang merujuk kepada kuasa yang menyertai perbuatan para rasul (Kis 4:33) dan peristiwa Stefanus (Kis 6:8). Dan selanjutnya, dapat dikatakan sebagai sesuatu yang yang terpenting, dimana sebenarnya Lukas hendak menunjuk pemakaian kuasa dalam Kis 1:8 yang berdampak pada keberanian murid-murid untuk bersaksi. Barrett menegaskan," This last reference contributes nothing, but the others may be added up to give the sense of jóvauls in 1:8." (Barret 2004). Kata dunamis diperoleh setelah Roh Kudus turun ke atas mereka, sehingga Kristus mengingatkan agar jangan meninggalkan Yerusalem untuk menantikan pencurahan Roh Kudus (Kis 1:5 bdg. Luk 24:49). Lebih lanjut Barrett menegaskan," The Holy Spirit is one of the major themes of Acts; some would say the central and most important theme."(Barret 2004). Inilah yang menyebabkan Lukas menggunakan bagian prolog ini untuk memperkenalkan Roh Kudus yang secara profetik telah dijanjikan oleh Bapa, bahwa akan segera datang. Kuasa Roh Kudus ini juga diperlihatkan oleh Lukas bekerja dalam kehidupan komunitas orang percaya. Inilah peran dan karya Roh Kudus dalam pembangunan kerajaan Allah yang ditunjukkan melalui pelayanan para rasul.

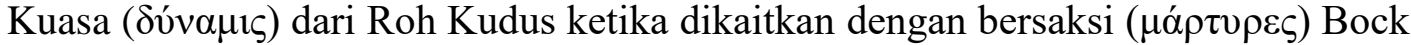
memberikan pengertian,"to being empowered to speak boldly by testifying to the message of God's work through Jesus (Bock 2007). Kuasa Roh Kudus bukan hanya memberikan keberanian untuk bersaksi, tetapi juga memberikan hikmat kepada para penginjil, misal seperti yang dialami oleh Stefanus dimana dengan penuh hikmat berbicara kepada Imam besar dalam memberikan pembelaan iman (Kis 7:1-53). Kuasa Roh Kudus dalam Kisah Para Rasul berkaitan erat dengan karunia Allah yaitu kemampuan mengadakan tanda-tanda dan mujizat untuk meneguhkan kesaksian yang diberitakan.

Kata "Bersaksi" ( $\mu$ ó $\rho \tau \rho \varepsilon \varsigma$, martures) memiliki akar kata dalam perjanjian lama yang merujuk pada kata "saksi" (Ibr $\hat{e} d$ ) dalam sebuah pengadilan. Kata "Bersaksi" ( $\mu \alpha ́ \rho \tau \nu \rho \varepsilon \varsigma$, martures) muncul sebanyak tiga belas kali dalam Kisah Para Rasul dari tiga puluh lima kali pemunculan dalam seluruh Perjanjian Baru (Bock 2007). Sementara kalau dilihat dalam kitab Yesaya menunjuk kepada saksi Allah (Yes 43:10-12). Frasa 'you will be my witnesses' (esesthe mou martyres) paralel dengan Yesaya 43:10 (bdk. 43:12, hymeis emoi martyres; 44:8). Peterson menjelaskan, "Isaiah envisages that the renewed people of God will be witnesses to the nations of the salvation of God when the new age arrives"(Peterson 2009). Dalam hal ini membuktikan bahwa bangsa Israel sebenarnya diberikan amanat oleh Allah akan panggilan untuk menjadi saksi Allah bagi bangsa-bangsa lain, namun umat Israel gagal. Dan panggilan itu kembali disampaikan Allah dalam perjanjian baru dimana dalam Kis 1:8 ini diperlihatkan bahwa menjadi saksi Kristus adalah panggilan utama umat percaya. 
Para murid dipanggil untuk menjadi saksi bagi Kristus, modal kesaksian mereka berasal dari pengalaman selama bersama dengan Yesus. Lukas memberikan penegasan bahwa modal utama yang dimiliki para murid untuk bersaksi bagi Kristus adalah kehidupan yang telah disaksikan dengan mata mereka mengenai Yesus Kristus, terlebih mengenai kebangkitan-Nya dari antara orang mati (bdg. Luk 24:48; Kis 1:22). Bahkan dapat dipastikan bahwa tujuan utama penulisan Kisah Para Rasul oleh Lukas ini adalah sebagai bentuk kesaksian yang bersifat dinamis yang tidak akan berhenti namun akan terus dilanjutkan oleh para penginjil sampai ke ujung bumi.

Hal ini dapat dilihat dalam kesaksian para rasul meskipun berada dalam tekanan yang berat namun tetap berani berkata," Sebab tidak mungkin bagi kami tidak berkata-kata tentang apa yang telah kami lihat dan yang telah kami dengar" (Kis 4:20). Dan dalam perkembangan kekristenan mula-mula kata ini dipergunakan untuk menyebutkan seorang yang bersaksi tentang segala kejadian atau peristiwa yang dilihat dengan mata mereka sendiri tentang apa yang dikerjakan, dialami oleh Yesus, dan merupakan peristiwa yang sungguh terjadi, maka mereka menjadi percaya kepada Yesus, dan disebut sebagai saksisaksi atas peristiwa tersebut dan memberitakan kepada banyak orang (Luk 24:48; Kis 2:32; $3: 15 ; 5: 32 ; 7: 58 ; 10: 39 ; 13: 31)$. Dan dampak dari apa yang mereka lihat dan saksikan tidak selalu membuat orang menjadi percaya dan serta merta menjadi pengikut Yesus, justru malah membawa mereka pada pengadilan-pengadilan agama, penganiayaan, penjara bahkan tidak sedikit pada kematian demi keyakinannya atau imannya kepada Kristus (Peterson 2009). Sehingga pada akhirnya istilah martir menjadi kata yang memiliki arti khusus yang dikenakan kepada orang yang bersaksi tentang Tuhan Yesus yang memiliki karakter setia, yang tidak takut kehilangan nyawanya demi kebenaran kerajaan Allah. Seperti pernyataan Origen bahwa akan ada pemeliharaan Allah dalam kemartiran," $n o$ one comes to the contest of martyrdom without providence (Malaty 1995)." Jadi Allah menggunakan kemartiran orang-orang percaya untuk menarik orang lain kepada iman kristen.

Meskipun Tuhan Yesus mati diatas kayu salib, namun tidak tepat jika kematiannya disebutkan sebagai tindakan martir. Karena kematian Tuhan Yesus diatas kayu salib tidak bisa disamakan dengan kematian-kematian yang dilakukan oleh para martir (pengikutnya). Sebab kematian Yesus diatas kayu salib adalah kematian yang sangat istimewa. Sedangkan tindakan kemartiran yang dilakukan oleh para murid adalah tindakan dalam mempertahankan kebenaran yang diyakininya yaitu kebenaran tentang Yesus Kristus, misalnya: Petrus mati disalib di Roma dengan kepada dibawah, Andreas yang memberitakan Injil di Rusia Selatan dan Bahkan mati dengan disalibkan bentuk "X" di Patras Yunani, Matius meninggal dunia dengan disiksa dan dibunuh dengan pedang di Ethopia, Markus meninggal di Alexandria (Mesir) setelah badannya diseret hidup-hidup dengan kuda melalui jalan-jalan yang berbatu-batu sampai menemukan ajalnya, Lukas mati digantung di Yunani setelah berkotbah kepada orang-orang yang belum mengenal Tuhan, Paulus juga mati martir, dieksekusi mati dibawah pemerintahan Kaisar Nero (Fox 2001). masih banyak lagi kemartiran yang dilakukan oleh para pengikut Kristus Karena iman mereka.

Kematian Yesus bukanlah kematian "martir" yang bermakna mati dalam mempertahankan kebenaran dan pemaksaan dari lawan-lawannya sampai akhir hidupnya, karena Yesus sendiri adalah kebenaran dan sumber kebenaran. Seseorang dapat menjadi martir sebagai tanda cinta dan bakti kepada Tuhan dan kebenaran-Nya, dan akhirnya dibunuh dalam kemartiran dimana Tuhan sebagai tempat bakti-Nya. Namun kematian Yesus bukanlah kematian martir, lebih tepatnya adalah kematian kurban, dimana Yesus merelakan jiwanya sendiri untuk dikurbankan demi kasih-Nya yang besar terhadap jiwa-jiwa yang berdosa. Dan jenis kematian seperti ini adalah sangat istimewa, kematian yang dilandaskan pada kasih yang tidak didasarkan pada dalil-dalil manusia yang melekatkan kebencian dan 
dendam atas nama Tuhan atau perjuangan. Kematian Yesus adalah inspirasi bagi muridmurid dan sumber dari semua kemartiran.

\section{Konsep Kemartiran}

Kemartiran sebenarnya tidak ada bedanya antara jaman sekarang dengan jaman kekristenan mula-mula. Karena martir itu berbicara tentang orang-orang yang bersaksi tentang Kristus sekalipun harus mengalami penganiayaan atau penderitaan berat demi mempertahankan iman keyakinannya bahkan sampai mati dan tidak menyangkalnya. Sedangkan hal yang membuat perbedaan adalah caranya seseorang menampilkan atau menyatakan Kristus ketika bertobat. Kehidupan para pengikut Yesus pada jaman gereja mula-mula begitu tekun dalam bersekutu dengan Tuhan. Karena mereka seperti orang yang baru terbangun dari mimpi dan mendapatkan sesuatu yang berharga. Sehingga begitu frontal dan beraninya mereka memberi kesaksian tentang imannya, baik kepada pemerintah maupun kepada para pemimpin agama. Dampaknya mereka langsung ditangkap, dianiaya dan diperhadapkan pada kematian.

Sedang pada kekristenan masa kini ada banyak strategi yang dapat dipergunakan agar pemberitaan Injil bisa aman dari jeratan hukum, ada juga peraturan yang melindungi ketika seseorang menjadi pengikut Kristus atau berpindah keyakinan (UUD 1945 Pasal 28E dan pasal 29), meskipun dalam prakteknya banyak diantara mereka yang mengalami diskriminasi maupun intimidasi bahkan sampai pada tindakan persekusi serta ada juga yang sampai mengalami kematian (Fox 2001). Sehingga manakala ada orang-orang yang masih baru bertobat strategi-strategi bijak yang dilakukan adalah membangun iman mereka terlebih dahulu, sehingga ketika sudah kuat mereka dapat memberikan kesaksian tentang iman dan pertobatannya. Jika pada saat iman belum kuat dan dipaksa tampil maka ketika mendapat tekanan masyarakat atau lingkungan mayoritas bisa kembali ke keyakinannya semula karena tekanan tersebut.

Dan juga pemberitaan Injil jaman dahulu tidak mengenal adanya undang-undang penodaan agama bahkan bidat-bidatpun dilawan tanpa takut adanya undang-undang penodaan agama (UU no. 1 PNPS th. 1965). Tetapi berbeda dengan kondisi keagamaan yang terjadi di Indonesia sekarang ini dimana kaum mayoritas masih berpegang dengan undangundang penodaan agama bahkan sering dipakai sebagai senjata pamungkas untuk menekan dan mendiskriminasi minoritas tatkala terdapat ancaman bagi agamanya dengan banyaknya orang-orang yang meninggalkan keyakinannya (www.nasional.com n.d.).Laranganlarangan seperti inilah yang membuat kehati-hatian untuk bersaksi dalam memberitakan iman Kristen. Bukan karena takut, tapi harus tetap bijak dan berhikmat. Seperti falsafah jawa "dapat ikannya tetapi tidak keruh airnya". Jadi sebenarnya sekalipun banyak hambatan baik yang bersifat politis, maupun kendala-kendala dari lingkungan, penderitaan, intimidasi, diskriminasi, persekusi bahakan sampai kepada kematian semangat kemartiran tetap terus digelorakan dari generasi ke generasi, sampai semua orang mendengar tentang Injil dan sampai pada kedatangan Kristus yang kedua kalinya.

\section{Spiritualitas Kemartiran}

Istilah spiritualitas seringkali disalahartikan dan dilihat sebagai sesuatu yang konteksnya sama dengan pandangan agama, keyakinan tertentu atau aturan moral dan tradisi - tradisi. Spiritualitas bukanlah sesuatu yang formal, terstruktur dan terorganisir seperti agama pada umumnya. Spiritualitas berasal dari kata 'spiritus' yang artinya adalah nafas kehidupan. Spirit merupakan kekuatan atau dorongan yang tidak terlihat yang memberikan nafas bagi kehidupan, menghidupkan dan memberikan energi. Spirit membantu dalam mendefinisikan kebenaran dan keunikan diri (Howard 2002). 
Berdasarkan tulisan Pinckaers dalam buku Spirituality of Martyrdom (Pinckaers 2016), spiritualitas memiliki beberapa pengertian, yaitu: (1). Metafisik, yaitu segala atribut yang berhubungan dengan spiritualitas jiwa, atau kekuatan yang memberikan dorongan, semangat atau spirit; (2). Devotion, yaitu segala sesuatu yang berkaitan dengan kebebasan jiwa dalam mencapai kesempurnaan di hadapan Tuhan.

Jadi pengertian spiritualitas berdasarkan uraian diatas lebih mengarah kepada spiritualitas jiwa atau spiritualitas batin, dimana spiritualitas yang terus dibangun akan membentuk dorongan yang memberikan kebebasan, semangat, spirit atau dorongan dalam mencapai kesempurnaan di hadapan Tuhan. Spirit merupakan bentuk pendeskripsian kuasa Roh Kudus yang diberikan oleh Tuhan karena hubungan dan persekutuan yang intim.

Tidak ada seorangpun yang secara spontan berhasrat mengalami penderitaan sebagai martir. Tidak ada seorangpun yang ingin mati ditengah siksaan dan hinaan atau sekedar mengalami siksaan secara fisik. Namun dalam sejarah perkembangan kekristenan tidak terhitung jumlah orang yang rela menderita dan mati demi mempertahankan keyakinan imannya. Kemartiran yang dilakukan bukan didasarkan pada tindakan paksaan namun dilakukan dengan penuh sukacita, dan penyerahan diri secara total kepada Allah. Hal ini didasarkan pada ucapan bahagia dalam kotbah Yesus di bukit, yang berbunyi: "Berbahagialah orang yang dianiaya oleh sebab kebenaran, karena merekalah yang empunya Kerajaan Sorga. Bersukacita dan bergembiralah, karena upahmu besar di sorga, sebab demikian juga telah dianiaya nabi-nabi yang sebelum kamu." (Mat 5:10-12 ITB)

Hal-hal penting yang mendasari tindakan kemartiran seseorang, yang pertama adalah keyakinan iman dan kasih kepada Kristus; dan yang kedua, pengakuan dalam tindakan, seperti yang tertulis," Setiap orang yang mengakui Aku di depan manusia, Aku juga akan mengakuinya di depan Bapa-Ku yang di sorga. Tetapi barangsiapa menyangkal Aku di depan manusia, Aku juga akan menyangkalnya di depan Bapa-Ku yang di sorga." (Mat 10:32-33 ITB). Orang-orang percaya sejati tidak menyimpan iman untuk dirinya sendiri tetapi menyatakan Kristus dalam perkataan, dalam tindakan dan dalam kehidupan; yang ketiga (Pinckaers 2016). Penderitaan yang diterima bahkan yang berakhir pada tindakan kemartiran merupakan harga yang harus dibayar. Kemartiran bukan hanya sekedar tanda yang memahkotai atau menyertai pengajaran-pengajaran para rasul ataupun para pemberita Injil Kristen, tetapi kemartiran telah menjadi dasar bagi kehidupan para pemberita Injil dan dasar perkembangan kekristenan. Hal ini seperti yang disampaikan oleh Tertullian, bahwa "darah martir adalah benih orang-orang Kristen", serta pernyataan dalam buku Apologynya yang mengatakan," semen est sanguis christianorum" yang artinya "darah orang Kristen adalah benih"(Tertullian 1885). Rasul Yohanes mencatat perkataan Tuhan Yesus mengenai benih, "Aku berkata kepadamu: Sesungguhnya jikalau biji gandum tidak jatuh ke dalam tanah dan mati, ia tetap satu biji saja; tetapi jika ia mati, ia akan menghasilkan banyak buah. (Yoh 12:24 ITB)"'.

Jadi apa yang dicatat oleh Rasul Yohanes mengenai benih biji gandum yang jatuh, mengacu pada tindakan kemartiran, dimana terdapat orang Kristen yang menjadi martir karena pemberitaan jalan kebenaran akan memunculkan pertobatan yang besar. Dan Inilah yang ditanamkan sebagai spiritualitas dari kemartiran. Dalam sejarah perkembangan kekristenan, diawal gereja mula-mula, kemartiran para pengikut Kristus telah membuat perkembangan kekristenan. Para pengikut Kristus atau para Rasul mengkotbahkan pemberitaan kabar baik tentang kedatangan kerajaan Allah di dalam Kristus Yesus, Mesias yang sudah dinubuatkan oleh para nabi, mengenai kelahiran, kematian dan kebangkitannya, bahkan setelah kenaikannya mengirimkan Roh Kudus yang memberikan semangat dan kehidupan baru, dan selanjutnya gereja mengalami pertumbuhan yang sangat pesat, terjadi pertobatan yang sangat besar. Sehingga dapat dikatakan bahwa pengajaran para Rasul yang 
berakhir pada kemartiran seperti sebuah energy spiritual yang sangat kuat yang mampu melawan segala rintangan dan perlawanan para penguasa pada masa itu (Pinckaers 2016).

Bahkan dalam liturgy di gereja Orthodoks, pada tanggal-tanggal kematian para martir sampai saat ini terus dibacakan untuk mengenang kisah kemartirannya, misal yang dialami oleh para Rasul, Bapa-bapa gereja, serta para martir lainnya (coptic Sinaxarion). Hal ini memberikan dampak terhadap kekuatan dan keteguhan iman bagi para jemaatnya. Kematian karena mengikut Kristus dan memberitakan Injil bukanlah kematian yang menyedihkan, tetapi justru menjadi kematian yang penuh sukacita, karena bisa menjadi bagian dalam salib penderitaan Kristus.

Jadi spiritualitas kemartiran merupakan kesadaran dan kepercayaan akan ajaranajaran Yesus, bahwa orang-orang kristen harus siap sedia dalam menanggung penderitaan dan aniaya. Spiritualitas juga merupakan dorongan yang berasal dari persekutuan dan hubungan pribadinya dengan Tuhan, yang menjadikan Tuhan sebagai yang diyakininya menjadi pribadi yang sangat berarti dari apapun juga, bahkan kematian sekalipun masih tidak sebanding dengan harga yang telah dibayarkan Tuhan untuknya. Para martir seperti mengundang umat Tuhan masa kini untuk memberikan kesaksian tentang imannya dalam Kristus dengan kecerdikan dan kesabaran, dengan setia dan kebanggaan, dan dengan pimpinan Roh Kudus. Mengajak pula untuk bersaksi melalui kesulitan, kontradiksi, godaan, dan penghinaan yang ditemui, dan membuktikan diri sebagai seorang hamba Allah yang berada dalam providensinya. Benih yang baik ditanam di ladang Allah untuk dituai di masa yang akan datang.

\section{Kemartiran Penginjilan Rasul Paulus berdasarkan Kisah Para Rasul}

Kisah Para Rasul banyak menuliskan mengenai perjalanan misi penginjilan Rasul Paulus. Kisah kemartiran hampir selalu melekat dalam perjalanan misinya. Ia menjadi martir sampai garis akhir.

\section{a. Latar Belakang kitab Kisah Para Rasul}

Keadaan Politik (Hemer 1973), melatarbelakangi zaman dalam kitab Kisah Para Rasul, dan hal ini sangat berkaitan dengan Antipater. Antipater adalah seorang yang tidak bermoral dan setelah Herodes mewariskan kerajaannya kepada ketiga putrinya. Herodes Arkhelaus menguasai daerah Yudea dan Samaria, Herodes Antipas menguasai Galilea serta bertanggung jawab atas kematian Yohanes pembaptis (Mat.14), dan Philip menguasai daerah timur dan timur laut Galilea. Beberapa tahun kemudian Arkhelaus dipindahkan dan digantikan Pilatus. Pilatus kemudian menjadi wali negeri yang paling terkenal (23-26M), dan juga dikenal sebagai seorang pencemooh adat istiadat orang Yahudi, tidak bijaksana dan bengis. Beberapa tahun kemudian, Antonius Felix (52-58M) dan Perkilus Festus (59-62M) menjadi wali negeri yang kemudian mengadili Paulus (Kis. 23:26). Berdasarkan peristiwaperistiwa yang terjadi setelah pemusnahan kota Yerusalem tahun 70M, maka beberapa penafsir memperkirakan bahwa penulisan kitab Kisah Para Rasul disusun sekitar tahun 8590M (Drewes. 2016).

Penulis dan Penerima kitab Kisah Para Rasul

Kitab Kisah Para Rasul dan Injil Lukas merupakan buah karya Lukas. Dengan melihat prakata Kisah Para Rasul (1:1), jelas mengingatkan prakata dalam Injil Lukas (1:14). Kedua kitab dipersembahkan kepada tokoh yang sama, bernama Teofilus. Teofilus adalah seorang yang berpendidikan, berkedudukan tinggi dan mempunyai latar belakang Kristen non Yahudi. Ia sudah menerima sedikit banyak penerangan mengenai agama Kristen, tetapi Lukas mengambil keputusan untuk menyediakan berita tersusun lebih teratur dan yang lebih dapat dipercaya untuknya (Ensiklopedia Alkitab Masa Kini, jilid II M-Z n.d.) . Dalam Kisah Para Rasul 1:1 juga penulis berkata tentang bukuku yang pertama yang 
tidak lain adalah Injil Lukas (Groenen 1997). Kenyataan ini menunjukkan adanya hubungan dengan Injil yang ditulis bagi orang yang sama.

Ikhtisar dari buku yang pertama, seperti yang termuat dalam Kisah Para Rasul 1:12, sangat sesuai dengan isi Injil Lukas dan cerita dimulai tepat pada titik di mana Injil Lukas berakhir. Tidak ada alasan yang dapat menyangkal jika Lukas dan Kisah Para Rasul adalah satu karangan dalam dua volume. Keduanya dimaksudkan supaya memenuhi suatu tujuan yang sama yaitu untuk meneguhkan iman dan memberikan suatu catatan sejarah yang dapat dimengerti tentang pernyataan Allah kepada semua manusia dalam karya Kristus, baik melalui dinamika kehidupan pribadi-Nya maupun melalui gereja-Nya (Tenney 1992).

Brink bahkan mengatakan bahwa tradisi tertua dengan suara bulat menunjuk kepada Lukas sebagai penulisnya. Walaupun nama penulis tidak dituliskan dalam kitab Kisah Para Rasul, namun permulaan ayat-ayatnya di mana Lukas memakai kata "kami" dengan jelas menunjuk kepada Lukas sebagai penulis. Beberapa Bapa Gereja, seperti Irenaeus, Klemens, dan Tertulianus juga menyatakan bahwa Lukas sebagai penulis Kisah Para Rasul (Brink 2008).

Mengenai jati diri penulis sendiri, Lukas diperkirakan dari kota Antiokhia dan bertobat ketika untuk pertama kali Injil diberitakan secara besar-besaran di kota itu. Disitulah Lukas berkesempatan untuk mengetahui tentang Tuhan dan ajaran-Nya bersama orang-orang Kristen angkatan pertama. Lukas kemudian menjadi rekan pelayanan Paulus yang terlibat langsung dalam berbagai kegiatan penginjilan, bahkan yang menyertai rasul Paulus dalam perjalanannya menuju Roma (Kis. 16:10-17; 20:5-15; 21:1-18; 27:1-28:16; Kol. 4:14; Flm. 24; 2 Tim. 4:11) (Tenney 1992). Beberapa ayat referensi lainnya menunjukkan bahwa Lukas adalah seorang tabib (Kol. 4:14; bdg. Mrk. 5:25-26; Luk. 8:43) dan juga dikenal sebagai seorang gembala sidang di Filipi (Kis. 19:1-41). Bukan hanya itu saja, selain dikenal sebagai seorang teolog, ia juga dikenal sebagai seorang sejarahwan. Itulah sebabnya tulisannya sangat akurat layaknya seorang sejarahwan yang berpendidikan tinggi (Santoso 2006)

Telah dipaparkan sebelumnya bahwa penerima kitab Kisah Para Rasul adalah sama dengan Injil Lukas, yaitu Teofilus. Namun bukan berarti bahwa Lukas hanya bermaksud untuk menulis kepada seorang pribadi saja. Sebenarnya alamat suratnya lebih luas, yakni mengalamatkan suratnya kepada orang-orang yang berlatar belakang agama kafir, sehingga mereka dapat melihat perbuatan-perbuatan Allah dan iman mereka dapat dikuatkan (Tulluan 1992).. Alasan untuk memperlihatkan bahwa umat Kristen adalah suatu lanjutan sejati dari apa yang dimulai dan dikerjakan Yesus. Tetapi pendapat tersebut merupakan suatu hipotesis yang sukar dibuktikan. Para ahli tafsir lainnya sepakat bahwa Lukas ditulis lebih dahulu dan beberapa tahun kemudian kitab Kisah Para Rasul ditulis. Hal ini dibuktikan dengan perkembangan pikiran dan pandangan Kisah Para Rasul yang lebih maju (Groenen 1997).

\section{b. Tujuan penulisan}

Kitab Kisah Para Rasul memberikan serangkaian informasi perbuatan berani dari figur-figur kepahlawanan yang besar pada masa Gereja Perdana, yang Lukas sendiri mempunyai tiga alasan saat menulis Kisah Para Rasul. Pertama, untuk merekomendasikan kekristenan kepada pemerintahan Romawi. Surat ini dibuat pada masa orang-orang Kristen dibenci dan dianiaya, namun Lukas memperlihatkan mengenai para pejabat Romawi yang dulunya bersikap adil terhadap kekristenan. Kedua, Lukas ingin menunjukkan bahwa kekristenan itu untuk semua bangsa (Kis 15). Jadi bukan hanya untuk umat Yahudi saja, tetapi untuk semua umat di manapun. Ketiga, yang merupakan tujuan utama, yaitu mengenai perkataan Yesus dalam 1:8. Perkataan Yesus ini dimaksudkan untuk menunjukkan penyebarluasan kekristenan dan untuk menunjukkan bagaimana agama yang berawal dari sebuah sudut kecil di Palestina, dalam kurun waktu kurang dari tiga puluh tahun telah 
menjangkau Roma (Newman, Barcley M. dan Nida 2008). Dapat disimpulkan bahwa tujuan utama penulisan Lukas adalah mengenai misiologi dan soteriologi.

Mendukung pernyataan Barclay di atas, Brink mengatakan bahwa maksud Kisah Para Rasul ialah melukiskan bagaimana Juru selamat yang dimuliakan dan bagaimana Roh Kudus bekerja dengan ajaib melalui perantaraan para rasul dan jemaat kristen mula-mula, hingga Injil dengan penuh kemenangan dibawa sampai ke Roma (Brink 2008). Lukas ingin menekankan bahwa apa yang telah diberikan Yesus disediakan juga bagi semua orang. Demikianlah Kisah Para Rasul 1:8 menjadi suatu kesaksian tentang dasar gereja Yesus Kristus serta menjadi pedoman bagi gereja Yesus Kristus di segala zaman. Inilah tujuan utama dari kitab Kisah Para Rasul, keselamatan bagi semua bangsa.

Analisis kemartiran penginjilan Rasul Paulus berdasarkan Kisah Para Rasul

Pemberitaan Injil yang dilakukan oleh jemaat kristen mula-mula hingga tersebar ke negara-negara lain, ke suku-suku bangsa merupakan inisiatif yang dikerjakan oleh Allah sendiri. Hal itu seperti yang tertulis dalam kitab suci, Yesus berkata, “...dan Aku, apabila Aku ditinggikan dari bumi Aku akan menarik semua orang datang kepada-Ku” (Yoh 12:32). Pada masa gereja mula-mula banyak terjadi penganiayaan dan penindasan, sehingga muridmurid tersebar ke negara-negara lain. Tuhan memanggil sosok Paulus yang sebelumnya bernama Saulus, tokoh yang memimpin penindasan dan penganiayaan terhadap orang-orang percaya untuk menjalankan misi pemberitaan Injil ke bangsa-bangsa lain. Paulus merupakan sosok terpelajar, berpengaruh dan sangat memahami budaya Yahudi maupun Yunani pada masa itu.

Model penginjilan yang dilakukan Paulus adalah berkotbah di sinagoge-sinagoge (Hakh 2010). Tetapi pada saat banyak orang Yahudi yang menolak Yesus, maka pemberitaan Injil beralih kepada bangsa-bangsa lain yang tidak mengenal Allah. Paulus sangat berani menyaksikan tentang Yesus, sehingga yang dahulunya adalah seorang penganiaya, telah berubah menjadi Paulus yang teraniaya. Orang-orang yang menolak pemberitaan Paulus mengenai keselamatan di dalam Yesus Kristus berusaha menghentikan dan membunuhnya (Hakh 2010). Pernah dilempari batu dan ditinggalkan mati, tetapi Allah telah menyelamatkannya (Hakh 2010). Hal ini terjadi dalam pelayanan misi penginjilannya yang pertama.

Dalam perjalanan misi berikutnya Paulus mengalami perlakuan yang tidak mengenakan yaitu dimasukkan ke dalam Penjara di Filipi namun justru kejadian ini membawa pertobatan kepala penjara (Kis 16:14-34) (Hakh 2010). Selanjutnya mengajar di rumah ibadat, dan banyak orang menjadi percaya atas pemberitaan Paulus mengenai Mesias yang dianiaya, menderita dan bangkit dari kematian. Sampai akhirnya diusir oleh orangorang Yahudi yang tidak percaya (Kis 17:1-9) (Hakh 2010). Selanjutnya menuju ke Berea dan mengajarkan tentang kitab suci dan banyak orang menjadi percaya, namun orang-orang Yahudi menghasut dan mengusir (Kis 17:14-15). Ia berkotbah juga di Aeropagus dengan mengatakan bahwa hanya Allah saja yang patut di sembah tanpa memerlukan patung-patung buatan tangan manusia, dengan mengutip satu tulisan di sebuah mezbah," Kepada Allah yang tidak dikenal (Kis 17:33)". Inilah model penginjilan kontekstual yang diajarkan Paulus, yang bersamaan dalam perjalanan misinya yang kedua.

Dalam perjalanan berikutnya Paulus dimasukan dalam penjara di Yerusalem (Kis 21:27 - 23:26). Lalu dikirim ke Roma dengan pengawalan yang ketat (Kis 27:1-28:16). Sesudah ditahan selama dua tahun di Roma, Paulus dibebaskan karena tidak terbukti bersalah. Perjalanan misi penginjilan Rasul Paulus banyak diwarnai dengan tindakantindakan kemartiran. Selain menghadapi pertentangan-pertentangan dari orang-orang Yahudi yang tidak mempercayai Yesus, Paulus juga berhadapan dengan para pengajarpengajar sesat atau bidat-bidat. Dalam perpisahan terakhirnya dengan para penatua jemaat dari gereja Efesus, Paulus memberikan pesan-pesan yang sangat penting bagi jemaat yang 
adalah tubuh Kristus, tentang bagaimana kehidupan pengajarannya yang selalu konsisten, tidak berubah-ubah. Paulus selalu mengajarkan tentang Kristus baik kelahiran, kehidupanNya, penderitaan, kematian dan kebangkitan-Nya. Paulus adalah seorang yang sangat rendah hati, seorang yang sangat konsisten dalam hidup, seorang yang selalu siap sedia sekalipun harus berhadapan dengan penjara dan seorang yang memiliki komitmen sampai akhir hidupnya. Paulus adalah seorang pribadi yang berpegang teguh pada integritasnya sebagai pengikut Kristus.

Rasul Paulus merupakan seorang missionaris terbesar yang pernah dikenal oleh dunia. Roh Kudus memanggilnya untuk tugas pelayanan yang besar yaitu kepada suku-suku bangsa, dengan panggilan yang begitu jelas yang pada akhirnya akan mempengaruhi dan menentukan arah hidupnya(Sills 2015). Dalam perjalanan misi pemberitaan Injil Rasul Paulus menjadikan Kristus sebagai pusat dalam pemberitaanNya. Bahkan dalam suratnya yang lain dikatakan, "Sebab yang sangat kurindukan dan kuharapkan ialah bahwa... Kristus dengan nyata dimuliakan di dalam tubuhku, baik oleh hidupku, maupun oleh matiku. Karena bagiku hidup adalah Kristus dan mati adalah keuntungan. Tetapi jika aku harus hidup di dunia ini, itu berarti bagiku bekerja memberi buah (Fil 1:20-22a)."

Rasul Paulus selalu optimis dan bersukacita ditengah-tengah penderitaanNya dalam pelayanan pemberitaan Injil (The 2006). Tantangan yang dihadapi dalam pelayanannya bukan hanya berasal dari orang Yahudi tetapi juga orang-orang non Yahudi yang menolak tentang keselamatan dalam Kristus Yesus. Penolakan-penolakan yang diterima sering membawa Paulus dalam penderitaan dan dalam penjara, bahkan dalam ancaman eksekusi mati, namun demikian Paulus tidak mengkuatirkan akan hidupnya, hal itu dapat dilihat dalam suratnya kepada Timotius, muridnya : 'Itulah sebabnya aku menderita semuanya ini, tetapi aku tidak malu; karena aku tahu kepada siapa aku percaya dan aku yakin bahwa Dia berkuasa memeliharakan apa yang telah dipercayakan-Nya kepadaku hingga pada hari Tuhan (2Tim 1:12 ITB). Beberapa kali menghadapi banyak ancaman penyiksaan dan pelemparan batu (Kis 14:5), dilempari sampai hampir mati dan diseret keluar kota (Kis 14:19), karena alasan politis harus diseret masuk penjara (Kis 16:21), diejek dan ditolak oleh masyarakat kafir (Kis 17:34), dan masih banyak lagi perjuangan Paulus dalam memberitakan Injil yang ditopang dengan semangat kerelaannya (The 2006) untuk mati bagi Tuhan (Kis 21: 13). Juga Pernyataannya kepada jemaat di Korintus bahwa Injil memiliki peran yang sangat penting dalam kehidupannya sehingga merasa berhutang jika tidak memberitakan Injil (1Kor 9:16). Bahkan walaupun berada dalam penjara Rasul Paulus tetap mengemban tugasnya sebagai pemberita Injil. Keyakinannya sangat kuat terhadap apa yang telah dipercayakan Tuhan kepadanya dan Tuhan memeliharakan yang telah dipercayakan itu sampai akhir hidupnya. Kesudahan dari semua penderitaan, penjara dan kematiannya adalah keselamatan dirinya. Kematian bukan bentuk pelarian dari apa yang dialaminya. Komitmen dan kasih Paulus dapat terlihat dari caranya memandang sesuatu dari sudut pandang Kristus, bukan dari sudut pandang manusia serta tidak pernah menyia-nyiakan kesempatan untuk tetap memberitakan Injil. Bahkan melalui kehidupannya dalam penderitaan banyak orang yang semakin dikuatkan imannya dan semakin berani dalam memberitakan Injil.

Rasul Paulus memberitakan Injil sampai pada akhir hayatnya. Dipenjarakan di Roma pada tahun 61 M. Setelah masa pemenjaraannya berakhir, kota Roma dibakar. Semula Kaisar Nero yang dipersalahkan atas pembakaran tersebut, oleh sebab itu untuk mengalihkan tuduhan ia menyalahkan orang-orang Kristen yang tinggal di Roma. Akibatnya penganiayaan besar terjadi. Pada masa itu Paulus ditangkap dan dimasukan kembali dalam penjara Roma. Dan diputuskan bersalah karena dituduh telah melakukan kejahatan dengan melawan Kaisar dan harus menerima hukuman mati. Dibawa ditiang eksekusi dan dipancung (Fox 2001). Rasul Paulus telah membuktikan keyakinan imannya menjadi saksi Kristus 
sampai pada akhir hidupnya, dan akhirnya mati sebagai martir, seperti yang pernah disampaikan sebelumnya dalam suratnya yang kedua kepada Timotius:

"Mengenai diriku, darahku sudah mulai dicurahkan sebagai persembahan dan saat kematianku sudah dekat. Aku telah mengakhiri pertandingan yang baik, aku telah mencapai garis akhir dan aku telah memelihara iman. Sekarang telah tersedia bagiku mahkota kebenaran yang akan dikaruniakan kepadaku oleh Tuhan, Hakim yang adil, pada hari-Nya; tetapi bukan hanya kepadaku, melainkan juga kepada semua orang yang merindukan kedatangan-Nya." (2Tim 4:6-8 ITB)

Dalam suratnya di Filipi dikatakan, "Sebab kepada kamu dikaruniakan bukan saja untuk percaya kepada Kristus, melainkan juga untuk menderita untuk Dia, (Flp 1:29 ITB)". Dunia di sekeliling orang-orang percaya tidak akan membiarkan iman Kristen bertumbuh kuat. Dunia akan terus berusaha membuat hambatan-hambatan jerat-jerat rohani yang ingin melumpuhkan iman Kristen. Oleh sebab itu orang-orang Kristen harus berjuang dari ketidakramahan dunia dalam mempertahankan iman kristennya. Menderita dalam pelayanan Injil adalah wajar bahkan merupakan karunia Tuhan untuk orang-orang percaya (Estabrooks 2001). Rasul Paulus telah memberikan pengajaran dalam hidupnya yang penuh dengan penderitaan, penganiayaan bahkan berakhir dengan kematian martir demi memberitakan tentang Kristus Yesus, hal ini pastinya akan membangkitkan semangat dalam memberitakan Injil.

\section{METODE PENELITIAN}

Penelitian ini menggunakan paradigma naturalistik, yaitu memahami tentang realitas perilaku seseorang atau pengalaman seseorang atau sekelompok orang. Sedangkan pendekatan yang dipergunakan dalam penulisan ini adalah pendekatan kualitatif yang dibangun dengan paradigma fenomenologi dengan karakteristik penelitian secara alamiah, naturalistik, kontekstual, bersifat menyeluruh, dan realitas bersifat terbuka. Peneliti menggunakan pendekatatan fenomenologi ini karena meneliti tentang perilaku manusia dengan melihat pola berpikir dan tindakan seseorang. Data dikumpulkan melalui observasi, wawancara maupun mempelajari dokumen tertulis.

Analisis data kualitatif dilakukan melalui data. Dengan mengklasifikasi, mencari pola serta mengumpulkan data untuk menemukan sesuatu yang dianggap penting, yang dapat dipelajari maupun yang dapat disampaikan kepada orang lain. Untuk melakukan analisa data digunakan analisis domain, analisis taksonomi, analisis komponensial dan analisis tema. Selanjutnya pembahasan analisis taksonomi, analisis komponensial dan analisis tema.

\section{HASIL DAN PEMBAHASAN}

\section{Analisis Domain}

Analisis domain dilakukan dengan grand tour observatian dan penelitian awal untuk mendapatkan topik dalam penelitian. Dari observasi dilapangan ditentukan topik dalam penelitian yaitu kemartiran penginjilan rasul Paulus berdasarkan Kisah Para Rasul. Dan dari hasil observasi ini peneliti menemukan bahwa: 1) Kurangnya pemahaman kemartiran Kelompok Kabar Baik. 2) Ketidaksesuaian pemahaman kemartiran antara yang tertulis dalam Kisah Para Rasul dengan yang terjadi di lapangan. 3) Kemartiran rasul Paulus dalam Penginjilan dapat menjadi teladan bagi Kelompok Kabar Baik dalam penginjilan tanpa rasa takut, lebih berani mengambil resiko dengan segala hikmat Allah serta mampu melakukan pertanggunganjawaban iman. 


\section{Analisis Taksonomi}

\section{a. Subfokus 1: Kemartiran dalam penginjilan rasul Paulus}

Pemahaman mengenai kemartiran dalam penginjilan rasul Paulus ini sangat penting bagi para pemberita Injil. Kemartiran rasul Paulus ditunjukkan dalam banyak hal selain memberitakan injil kepada bangsa-bangsa yang belum mengenal Kristus, mengakibatkan kelaparan, penderitaan dan kesusahan. Juga manakala melakukan pertanggungjawaban iman dalam menghadapi pengajar-pengajar sesat, para ahli-ahli filsafat yang membuatnya dimusuhi dan mengalami penderitaan dan puncaknya ketika menghadapi pertentangan dari orang-orang Yahudi yang menolak pemberitaan Kristus yang berakibat pada penderitaan, penganiayaan, pemenjaraan bahkan pada kematian.

\section{b. Subfokus 2: Kemartiran dalam penginjilan Kelompok Kabar Baik di Malang}

Kelompok Kabar Baik sebagai perkumpulan hamba-hamba Tuhan yang terjun langsung di lapangan dalam memberitakan injil, dengan menggunakan berbagai model serta strategi agar aman dari jeratan hukum, perlu melihat strategi rasul Paulus baik dalam berhadapan dengan orang-orang yang belum percaya, dengan pengajar-pengajar sesat maupun dengan para penguasa. Penginjilan tentunya akan menerima berbagai resiko, sekalipun melakukannya sudah dengan penuh kehati-hatian.

\section{c. Subfokus 3: Model Kemartiran dalam penginjilan rasul Paulus berdasarkan Kisah Para Rasul terhadap Kelompok Kabar Baik di Malang}

Dari hasil yang diperoleh pada pertanyaan subfokus 3, Kelompok Kabar Baik perlu meneladani model kemartiran rasul Paulus dalam penginjilan. Untuk melakukan penginjilan tanpa rasa takut, penuh hikmat, penuh keberanian sekalipun harus berhadapan dengan penderitaan bahkan kematian.

\section{Analisis Komponensial}

\section{a. Subfokus 1: Kemartiran dalam penginjilan rasul Paulus}

Kemartiran dalam penginjilan rasul Paulus dilakukan atas dasar pemahaman yang benar terhadap iman dan keyakinannya kepada Allah sehingga membawa dampak yang sangat signikan dalam perkembangan kerajaan Allah. Dengan memiliki motivasi yang benar dalam pemberitaan injil serta ditopang dengan spirit atau kuasa Roh Kudus menjadikan segala tindakan yang dilakukan adalah untuk memulikan Allah dengan tanpa pamrih. Serta mampu mempertahankan iman dari orang-orang yang meminta pertanggungjawaban dengan penuh kepasrahan dan penyerahan diri.

\section{b. Subfokus 2: Kemartiran dalam penginjilan Kelompok Kabar Baik di Malang}

Dari hasil penelitian di lapangan peneliti memperoleh gambaran bahwa kelompok Kabar Baik memiliki pemahaman yang baik mengenai kemartiran dalam penginjilan. pemahaman ini tentunya sangat bagus untuk tindakan ke depannya. Paulus adalah teladan baik dalam mengajarkan kemartiran maupun dalam tindakan kemartiran. Paulus merupakan teladan orang yang berintegritas, bukan hanya fasih dalam mengajarkan kebenaran, mengajarkan orang dalam pengenalan akan Tuhan, namun melalui tindakan-tindakan yang 
dikerjakan dalam menghadapi kesulitan dan penderitaan menunjukkan sikap orang yang sangat kenal betul dengan pribadi yang disembah dan mengutusnya.

\section{c. Subfokus 3: Model Kemartiran dalam penginjilan rasul Paulus berdasarkan Kisah Para Rasul terhadap Kelompok Kabar Baik di Malang}

Para informan menyadari bahwa teladan hidup yang ditunjukkan oleh rasul Paulus adalah tindakan yang keluar dari pemahaman yang benar. Prinsip-prinsip kemartiran Paulus dalam penginjilan dapat dilihat dari sikapnya yang penuh kerendahan hati dalam mengajar kepada orang lain atau berhadapan dengan orang lain. Paulus adalah orang yang sangat konsisten dalam hidupnya perkataan dan perilakunya tidak penuh kemunafikan tapi seirama dan serasi. Selalu mengajarkan kebenaran dan bersaksi dengan tanpa malu dan takut, memiliki hubungan yang intim dengan Tuhan yang dapat dilihat dari pesan-pesan Roh Kudus yang keluar dari pengajaran dan kesaksiannya, dan memiliki komitmen sampai akhir sekalipun penuh dengan penderitaan bahkan berakhir dengan kematian sekalipun.

\section{d. Analisis Tema}

Pada analisis tema ini ditemukan tema umum yaitu kemartiran dalam penginjilan rasul Paulus berdasarkan kitab Kisah Para Rasul terhadap Kelompok Kabar Baik di Malang. Sedangkan dalam tema khusus ditemukan: penerapan praktis pemahaman kemartiran, pemahaman motivasi dalam kemartiran, pemahaman spiritualitas dalam kemartiran, pengajaran strategi penginjilan, dan penerapan prinsip-prinsip kemartiran dalam kehidupan sehari-hari.

Sedangkan berdasarkan temuan dari analisis data peneliti mengusulkan suatu model yang dapat diterapkan dalam penginjilan Kelompok Kabar Baik yaitu model strategi bersaksi sampai garis akhir, dengan mendasarkan pada prinsip-prinsip kemartiran rasul Paulus berdasarkan Kisah Para Rasul, serta dengan memperhatikan tantangan yang dihadapi dalam pelayanan dan ditopang dengan keteladanan hidup yang saleh.

Model yang ditemukan ini merupakan penggabungan antara teks dan konteks. Teks karena mendasarkan pada kajian teori mengenai kemartiran dalam penginjilan rasul Paulus berdasarkan kitab Kisah Para Rasul. Konteks yaitu dengan mendasarkan pada pandangan yang diberikan oleh para informan dalam penelitian. Konteks Rasul Paulus disebut sebagai seorang martir karena telah berjuang dengan darah dan air mata, perjuangan penuh dengan tantangan dan penderitaan bahkan berakhir dengan kematian. Penginjilan yang dikerjakan oleh Kelompok Kabar Baik tentunya belum seperti yang dilakukan oleh rasul Paulus, namun semangat penginjilan dengan menggunakan berbagai macam strategi perlu diberikan apresiasi. Apakah penerapan strategi ini sebagai bentuk ketakutan kalau berhadapan dengan hukum atau sebagai strategi agar penyampaian berita tentang kabar baik bisa terus disampaikan sampai garis akhir hidup tanpa harus terlibat hukum maupun penistaan terhadap keyakinan agama lain.

\section{SIMPULAN}

Kemartiran bukan hanya berbicara tentang mereka yang telah mati dalam Tuhan. Tetapi juga berbicara tentang mereka yang karena kesaksian akan imannya dalam Yesus 
Kristus harus mengalami penderitaan, siksaan, dan penganiayaan daripada harus meninggalkan imannya.

Jadi kesimpulan yang diperoleh dalam penulisan ini adalah sebagai berikut: pertama, kemartiran dalam penginjilan rasul Paulus adalah tindakan nyata yang dilakukan oleh seorang pengikut Kristus, yang tetap mempertahankan imannya dalam menghadapi segala tantangan. Paulus tidak hanya berbicara tentang konsep kemartiran namun menunjukkan sendiri bagaimana menjadi seorang martir sejati. Kedua, kemartiran merupakan tindakan seseorang dalam bersaksi memberitakan injil keselamatan, mengalami penderitaan, kesusahan, dan penganiayaan sampai mati. Ketiga, kemartiran merupakan tindakan dari seseorang yang mengalami penderitaan fisik sekujur tubuhnya karena imannya akan Kristus, mengalami siksaan berat sekalipun tidak sampai mati. Keempat, penelitian ini bertujuan untuk menemukan suatu model kemartiran terhadap kelompok penginjilan Kelompok Kabar Baik, dengan memperhatikan prinsip-prinsip kemartiran rasul Paulus berdasarkan kitab Kisah Para Rasul dan dengan memperhatikan tantangan yang ada dalam penginjilan serta juga ditopang dengan keteladanan hidup yang berdasarkan kebenaran firman Tuhan.

Serta dengan memperhatikan strategi penginjilan yang selama ini dikerjakan oleh kelompok kabar baik peneliti mengusulkan suatu model kemartiran yaitu model strategi bersaksi sampai garis akhir, yaitu suatu model bersaksi yang dikerjakan selama terus menerus sekalipun ada atau tidak ada tantangan, sekalipun harus berhadapan dengan penjara pemberitaan injil harus disampaikan sampai garis akhir, sampai akhir hayat.

\section{DAFTAR PUSTAKA}

"Alkitab Elektronik: Bibleworks Ver. 8."

Barret, C.K. 2004. International Critical Commentary : Acts. Eugene, Oregon: Wipf \& Stock Pub.

Bock, Darrell L. 2007. Baker Exegetical Commentary on the New Testament: Acts. Grand Rapids, Michigan: Baker Academic.

Brink, H. van de. 2008. Tafsir Alkitab: Kisah Para Rasul. Jakarta: BPK Gunung Mulia.

Drewes., B.F. 2016. Tafsiran Alkitab Kisah Para Rasul. Jakarta: BPK Gunung Mulia. "Ensiklopedia Alkitab Masa Kini, Jilid II M-Z." https://www.britannica.com/topic/martyr (February 1, 2020).

Estabrooks, Paul. 2001. Berdiri Teguh Di Tengah Badai, Sebuah Manual Untuk Pengikut Yesus Kristus Dalam Menghadapi Penderitaan Dan Aniaya. Jakarta: Open Doors International.

Fox, John. 2001. Foxe's Book of Martyrs, Kisah Para Martir. Yogyakarta: Penerbit Andi. Groenen, C. 1997. Pengantar Ke Dalam Perjanjian Baru. Yogyakarta: Penerbit Kanisius. Hakh, Samuel Benyamin. 2010. Perjanjian Baru, Sejarah, Pengantar Dan Pokok-Pokok Teologisnya. Bandung: Bina Media Informasi.

Hemer, Collin. 1973. “Latar Belakang Sejarah Dan Politik Dari Perjanjian Baru,” Dalam Pedoman Lengkap Pemahaman Alkitab. Bandung: Yayasan Kalam Hidup.

Howard, S. 2002. "A Spiritual Perspective On Learning In The Workplace, Lancaster: Lancaster University.” Journal Of Managerial Psychology, 17 (3).

Malaty, Fr Tadros Y. 1995. Lectures in Patrology the School of Alexandria, Book One Before Origen. Jersey City: St. Mark's Coptic Orthodox Church.

Newman, Barcley M. dan Nida, Eugene A. 2008. Pedoman Penafsiran Alkitab: Kisah Para Rasul. Jakarta: Lembaga Alkitab Indonesia.

Nielsen, J.T. 2015. Tafsiran Alkitab Kitab Injil Matius 23-28. Jakarta: BPK Gunung Mulia. Peterson, David G. 2009. The Acts of the Apostles, The Pillar New Testament Commentary. 
Grand Rapids, Michigan: Wm B. Eerdmans Publishing Co.

Pinckaers, Servais. 2016. Spirituality of Martyrdom... To The Limits of Love, Translated by

Patrick M. Clark and Annie Hounsokou. Washington DC: The Catholic University of America Press.

Santoso, David Imam. 2006. Theologi Lukas: Intisari Dan Aplikasinya. Malang: Literatur SAAT.

Sills, M. David. 2015. Panggilan Misi. Surabaya: Momentum.

Sutanto, Hasan. 2006. Perjanjian Baru Interlinear Yunani - Indonesia Dan Konkordansi

Perjanjian Baru Jilid II. Jakarta: Lembaga Alkitab Indonesia.

Takaliuang, Pondsius. Diktat Kuliah Martyrology Atau Kesyahidan. Batu.

Tenney, Merril C . 1992. Survei Perjanjian Baru. Malang: Penerbit Gandum Mas.

Tertullian. 1885. “Apology,” Ch. 50. 1885. in Ante-Nicene Fathers, Trans. Sydney

Thelwall. ed. and A. Cleveland Coxe. Alexander Roberts, James Donaldson. Buffalo,

N.Y.: Christian Literature Publishing.

The, Johny. 2006. Menjadi Pemimpin Unggul Dengan Strategi Marketing Paulus.

Yogyakarta: Penerbit Andi.

Tulluan, Ola. 1992. Introduksi Perjanjian Baru. Malang: STT I3.

Witherington III, Ben. 1998. The Acts of the Apostles: A Socio-Rhetorical Commentary.

Grand Rapids, Michigan: Wm. B. Eerdmans Publishing Co.,.

"Www.Nasional.Com." www.Nasional.kompas.com.

Yewangoe, A.A. 1989. Theologia Crucis Di Asia. Jakarta: BPK Gunung Mulia. 